\title{
Diversity within cyanobacterial mat communities in variable salinity meltwater ponds of McMurdo Ice Shelf, Antarctica
}

\author{
Anne-Dorothee Jungblut, ${ }^{1}$ lan Hawes, ${ }^{2}$ \\ Doug Mountfort, ${ }^{3}$ Bettina Hitzfeld, ${ }^{4}$ Daniel R. Dietrich, ${ }^{5}$ \\ Brendan P. Burns ${ }^{1}$ and Brett A. Neilan ${ }^{1 *}$ \\ ${ }^{1}$ University of New South Wales, Australia. \\ ${ }^{2}$ National Institute of Water and Atmospheric Research, \\ New Zealand. \\ ${ }^{3}$ Cawthron Institute, New Zealand. \\ ${ }^{4}$ Swiss Agency for the Environment, Forests and \\ Landscape, Switzerland. \\ ${ }^{5}$ University of Konstanz, Germany.
}

\section{Summary}

This study investigated the diversity of cyanobacterial mat communities of three meltwater ponds - Fresh, Orange and Salt Ponds, south of Bratina Island, McMurdo Ice Shelf, Antarctica. A combined morphological and genetic approach using clone libraries was used to investigate the influence of salinity on cyanobacterial diversity within these ecosystems without prior cultivation or isolation of cyanobacteria. We were able to identify 22 phylotypes belonging to Phormidium sp., Oscillatoria sp. and Lyngbya sp. In addition, we identified Antarctic Nostoc sp., Nodularia sp. and Anabaena sp. from the clone libraries. Fresh (17 phylotypes) and Orange (nine phylotypes) Ponds showed a similar diversity in contrast to that of the hypersaline Salt Pond (five phylotypes), where the diversity within cyanobacterial mats was reduced. Using the comparison of identified phylotypes with existing Antarctic sequence data, it was possible to gain further insight into the different levels of distribution of phylotypes identified in the investigated cyanobacterial mat communities of McMurdo Ice Shelf.

\section{Introduction}

Cyanobacteria are the dominant primary producers in extreme permafrost environments of the aquatic systems on McMurdo Ice Shelf, Antarctica. They are also one of the oldest groups of organisms and are thought to be the

Received 1 March, 2004; revised 6 July, 2004; accepted 8 July, 2004. ${ }^{*}$ For correspondence. E-mail b.neilan@ unsw.edu.au; Tel. (+61) 29385 3235; Fax (+61) 293851591. first oxygenically active organisms with fossil findings confirming the antiquity (Castenholz and Waterbury, 1989). Cyanobacteria are of key interest for a better understanding of the evolution of their present diversity and mechanisms of adaptation, which are essential for their survival in cold environments.

The McMurdo Ice Shelf comprises an area of about $1500 \mathrm{~km}^{2}$ with a thickness from 10 to $50 \mathrm{~m}$ (Swithnbank, 1970; Howard-Williams et al., 1990). During the summer, the area is covered with a network of meltwater ponds that vary in size, shape and physicochemical conditions, even though some of them are only several meters apart (De Mora et al., 1991). Three of these ponds, Fresh, Orange and Salt Ponds, have been intensively studied with regard to their physicochemical parameters as well as the morphological diversity of cyanobacteria, protozoa, rotifers, tardigrades and nematodes present (Howard-Williams et al., 1990). High salinities in these ponds originated from diluted seawater or chemical weathering of sedimentary material such as the dissolution of mirabilite $\left(\mathrm{Na}_{2} \mathrm{NO}_{3} \mathrm{SO}_{4} \mathrm{H}_{2}\right)$ and thernadite $\left(\mathrm{Na}_{2} \mathrm{SO}_{4}\right)$, in combination with small amounts of gypsum $\left(\mathrm{CaSO}_{4} \mathrm{H}_{2} \mathrm{O}\right)$ (Keys and Williams, 1981; De Mora et al., 1994).

In these hypersaline environments, cyanobacteria need to maintain their intracellular osmotic equilibrium and cell turgor to ensure survival through mechanisms such as the production of organic osmolytes (Oren, 2000). High UV radiation is another major stress factor for cyanobacteria in Antarctic aquatic ecosystems on McMurdo Ice Shelf (Ross and Vincent, 1998), which can lead to the photoinhibition of photosynthesis, mutagenesis, or chlorophyllbleaching (Castenholz, 1992; Ehling-Schulz and Scherer, 1999).

Cyanobacteria are often found in the form of thick microbial benthic mats, having a characteristic vertical stratification of different functional microbial groups (Howard-Williams et al., 1989). Cyanobacteria are most dominant in the top layer of these mats (Stal et al., 1985) and motile species such as Oscillatoriales, as well as the nitrogen-fixing Nostocales, are very prominent in these communities (Howard-Williams et al., 1990).

Previous attempts to classify species in these ponds have relied on traditional microscopic studies (HowardWilliams et al., 1990; Broady and Weinstein, 1998) and 
Table 1. Physicochemical conditions of the meltwater ponds - Fresh, Orange and Salt Ponds, McMurdo Ice Shelf, Antarctica.

\begin{tabular}{lclllll}
\hline Site & Conductivity $(\mu \mathrm{S} / \mathrm{cm})$ & $\mathrm{DRP}^{\mathrm{a}}\left(\mathrm{mg} / \mathrm{m}^{3}\right)$ & $\mathrm{NH}_{4}-\mathrm{N}^{\mathrm{b}}\left(\mathrm{mg} / \mathrm{m}^{3}\right)$ & $\mathrm{NO}_{3}-\mathrm{N}^{\mathrm{c}}\left(\mathrm{mg} / \mathrm{m}^{3}\right)$ & $\mathrm{DOP}^{\mathrm{d}}\left(\mathrm{mg} / \mathrm{m}^{3}\right)$ & $\mathrm{DON}^{\mathrm{e}}\left(\mathrm{mg} / \mathrm{m}^{3}\right)$ \\
\hline Fresh Pond & 158 & 5.5 & 18 & 2 & 34 & 1131.5 \\
Orange Pond & 937 & 39 & 18.5 & 2.5 & 99 & 2080.5 \\
Salt Pond & 52900 & 29 & 50.5 & 4 & 565.5 & 13356.5 \\
\hline
\end{tabular}

a. Dissolved reactive phosphorous.

b. Ammonium.

c. Nitrate.

d. Dissolved organic phosphorous.

e. Dissolved organic nitrogen.

culturing of morphotypes (Nadeau et al., 2001). Because of the variable morphological appearance of cyanobacteria depending on the prevailing environmental conditions, this traditional approach of characterizing cyanobacteria is very difficult. Additionally, culturing only provides limited information on the composition of communities because of selectivity. In the present study, benthic cyanobacterial mat communities of three meltwater ponds on McMurdo Ice Shelf were investigated for the first time via a polyphasic morphological and genotypic approach. These meltwater ponds are Fresh, Orange and Salt Ponds (unofficial names), and they are situated south of Bratina Island on McMurdo Ice Shelf. The ponds were chosen because of their significant differences in salinities and physicochemical parameters described above.

Cyanobacterial mats are not only a dominant feature of Antarctic ecosystems, but also in Arctic as well as other extreme environments such as hot springs and desert crusts (Rudi et al., 1997; Ward et al., 1998; Vincent, 2000a; Wynn-Williams, 2000). Therefore, it is of interest to compare the diversity of these mats on McMurdo Ice Shelf in the context of speciation and physiological adap- tation and distribution, using a polyphasic characterization. Finally, this study will also address the question of the role of the McMurdo meltwater ponds as biotic pools for the aquatic systems in the ice-free regions of Victoria Land during interglacial periods (Howard-Williams et al., 1990; Vincent, 2000a).

\section{Results}

\section{Conductivity}

The investigated McMurdo meltwater ponds Fresh, Orange and Salt Ponds had very different conductivities (Table 1). The highest conductivity was measured in Salt Pond with $52900 \mu \mathrm{S} / \mathrm{cm}$. In Orange Pond the conductivity was $937 \mu \mathrm{S} / \mathrm{cm}$ and the lowest conductivity was found in Fresh Pond with only $158 \mu \mathrm{S} / \mathrm{cm}$.

\section{Morphological diversity}

The cyanobacterial mat communities in the three meltwater ponds investigated were dominated by cyanobacteria belonging to the filamentous orders Oscillatoriales and Nostocales (Table 2). Nostoc sp. and Nodularia sp. were

Table 2. Identified morphogroups and species of the cyanobacterial mat communities in the meltwater ponds - Fresh, Orange and Salt Ponds, McMurdo Ice Shelf, Antarctica.

\begin{tabular}{|c|c|c|c|c|c|c|}
\hline Order & Genus & $\begin{array}{l}\text { Morphogroups } \\
\text { (tichome-width) }\end{array}$ & Species & Fresh pond & Orange pond & Salt pond \\
\hline \multirow[t]{12}{*}{ Oscillatoriales } & $\begin{array}{l}\text { Oscillatoria } \\
\text { Phormidium }\end{array}$ & & & & & \\
\hline & Lyngbya & $\mathrm{A}:<3 \mu \mathrm{m}$ & & + & + & + \\
\hline & & & $\begin{array}{l}\text { P. cf. deflexum } \\
\text { (Anagnostidis and Komarek) }\end{array}$ & + & + & + \\
\hline & & & O. cf. fragile (Gom) & & + & \\
\hline & & & P. cf. Priestleyi (Fritsch) & & & + \\
\hline & & & Lyngbya cf. limnetica & & + & \\
\hline & & B: $3-5 \mu \mathrm{m}$ & & + & + & + \\
\hline & & C: $5-9 \mu \mathrm{m}$ & & + & + & + \\
\hline & & & $\begin{array}{l}\text { Osc cf. priestleyii } \\
\text { (West and West) }\end{array}$ & + & & + \\
\hline & & & $\begin{array}{l}\text { P. cf. autumnale } \\
\text { (Anagnostidis and Komarek) }\end{array}$ & + & + & \\
\hline & & D: $9-12 \mu \mathrm{m}$ & & & + & \\
\hline & & & $\begin{array}{l}\text { Oscillatoria cf. limosa } \\
\text { (Anagnostidis and Komarek) }\end{array}$ & & + & \\
\hline \multirow[t]{3}{*}{ Nostocales } & Nostoc & & & + & + & \\
\hline & Nodularia & & & + & + & + \\
\hline & & & N. cf. harveyana (Thuret) & + & + & + \\
\hline
\end{tabular}


observed from the order Nostocales. The morphotypes belonging to Oscillatoriales were identified as Phormidium sp., Oscillatoria sp. and Lyngbya sp. Four morphogroups were defined for morphotypes belonging to Oscillatoriales but did not agree clearly with the oscillatorian identification keys. These morphogroups were distinguished on the basis of the width of the trichome such as trichome width $<3 \mu \mathrm{m}$ (morphogroup A), 3-5 $\mu \mathrm{m}$ (morphogroup B), 5-9 $\mu \mathrm{m}$ (morphogroup C) and 9-12 $\mu \mathrm{m}$ (morphogroup D). Following this approach, Orange Pond exhibited the largest diversity of morphotypes. The number of identified morphotypes in Fresh Pond was slightly lower and the lowest morphological diversity was observed in Salt Pond.

Nodularia cf. harveyana (Kuetz) was present in all three ponds. However, it appeared that these heterocystous cyanobacteria were more prominent in Fresh and Orange Ponds than in Salt Pond. Nostoc sp. was only observed in Orange and Fresh Ponds. In Orange Pond the oscillatorian species P. cf. deflexum, Lyngbya cf. limnetica, Oscillatoria priestley, P. autumnale, O. cf. fragile and Oscillatoria limosa were identified. In Fresh and Salt Ponds, the morphogroups A, B and C were abundant as were $P$. cf. deflexum and $O$. priestley. Additionally, $P$. autumnale was identified in Fresh and Orange Ponds.

\section{Phylogenetic diversity}

One hundred and two clones from the cyanobacterial mat community of Orange Pond, 100 from Salt Pond and 115 from Fresh Pond were obtained. These 16S rDNA clones from the three communities were screened with the two restriction enzymes, $A / U$ l and $S c r F I$ (data not shown). Two clones were chosen from each novel restriction enzyme pattern for sequencing to evaluate the levels of discrimination of the amplified restriction digest rDNA analysis (ARDRA), and to determine the 16S rDNA sequence of each restriction pattern type.

Phylogenetic analysis was performed using reference sequence data from the orders Oscillatoriales and Nostocales. Sequence data of the orders Pleurocapsales, Chroococcales and Prochloron were excluded, because the clones did not show a high similarity to these orders in the GenBank (NCBI) BLAST searches. Sequence data from other Antarctic environments and various Arctic strains were also used in the analysis to assess the geographical distribution of the uncultured cyanobacterial clones from the three ponds (Table 3). The Antarctic references originated from Lake Fryxell and Lake Bonney in the Dry Valleys, Vestfold Hills (East Antarctica) and the meltwater system south of Bratina Island (McMurdo). We were able to obtain sequence data of isolates from several meltwater ponds south of Bratina Island, as well as sequence data from Salt and Orange Ponds. Sequences were included when they were the closest match in the GenBank (NCBI) BLAST to sequences obtained in the present study, and when that species was morphologically identified in this study.

The sequences from the three clone libraries grouped into 12 different clusters. Four of these clusters were formed in the order Nostocales, comprising seven different phylotypes, whereas eight clusters belonged to the Oscillatoriales containing 19 different phylotypes (Table 4).

Table 3. Antarctic and Arctic reference sequences.

\begin{tabular}{|c|c|c|}
\hline Location & Sequence(s) & Reference \\
\hline \multicolumn{3}{|l|}{ Antarctica } \\
\hline $\begin{array}{l}\text { Meltwater ponds south of Bratina } \\
\text { Island, McMurdo Ice Shelf }\end{array}$ & $\begin{array}{l}\text { Oscillatoria sp. Ant-G16, Ant-G17, Ant-Pancreas, } \\
\text { Ant-Salt, Ant-SOS Phormidium sp. Ant-Brack2, } \\
\text { Ant Brack3, Ant-Lunch, Ant-Orange, Ant-Skua }\end{array}$ & Nadeau et al. (2001) \\
\hline $\begin{array}{l}\text { Lake Fryxell, McMurdo } \\
\text { Taylor Valley }\end{array}$ & $\begin{array}{l}\text { Uncultured clones BGC-Fr080, FR132, Fr054, FR147, } \\
\text { Fr391, Fr239, FrE313, FR048, FR005, FR032, } \\
\text { FR304, FR304, FR397, FR239, FR094, FR127, } \\
\text { BGC-FR056, BGC-Fr032, Fr121 }\end{array}$ & Taton et al. (2003) \\
\hline Lake Bonney, McMurdo Dry Valley & Uncultured clones LB3-7, LB3-46, LB3-75, LB3-76 & Priscu et al. (1998) \\
\hline Pond, McMurdo Ice Shelf & P. murrayii UTCC475 & D.A. Casamatta and M.L. Vis, unpubl. data \\
\hline Pond, McMurdo Ice Shelf & Phormidium subfuscum UTCC474 & D.A. Casamatta and M.L. Vis, unpubl. data \\
\hline Pond, McMurdo Ice Shelf & O. priestleyii UTCC476 & D.A. Casamatta and M.L. Vis, unpubl. data \\
\hline Pond, McMurdo Ice Shelf & Phormidium sp. NIVA-CYA177 & Rudi et al. (1997) \\
\hline Quartz stones, Vestfold hills & Uncultured clones QSSC9L-3, QSSC8L-5 & Smith et al. (2000) \\
\hline $\begin{array}{l}\text { Beacon sandstone, } \\
\text { McMurdo Dry Valley }\end{array}$ & Uncultured clones FBP 403 & de la Torre et al. (2003) \\
\hline \multicolumn{3}{|l|}{ Arctic } \\
\hline Pond, Canadian Arctic & Oscillatoria sp. strain E17 & Nadeau et al. (2001) \\
\hline Pond, Canadian Arctic & Phormidium sp. strain E18 & Nadeau et al. (2001) \\
\hline Norwegian Arctic & Phormidium sp. strain NIVA-CYA 202 & Rudi et al. (1997) \\
\hline Norwegian Arctic & Phormidium sp. strain NIVA-CYA 203 & Rudi et al. (1997) \\
\hline Norwegian Arctic & Nostoc sp. strain NIVA-CYA 308 & Rudi et al. (1997) \\
\hline
\end{tabular}


Table 4. Phylotypes of the obtained clones from the clone library of sample Fresh, Orange and Salt Ponds.

\begin{tabular}{|c|c|c|}
\hline Clones & Closest BLAST match, GenBank & Similarity (\%) \\
\hline OraP01, OraP02, OraP04, FreP01 & Uncultured clone Fr 032, Phormidium sp. Ant-Orange & 98 \\
\hline OraP03, OraP05 & Phormidium sp. Ant-Orange & 99 \\
\hline $\begin{array}{l}\text { OraP06, OraP07 OraP08, OraP09, FreP08, FreP09, } \\
\text { FreP10, FreP11, FreP12, FreP13, FreP14 }\end{array}$ & Uncultured clone Fr132 & 99 \\
\hline OraP10 & Uncultured clone LB45, LB46 & 95 \\
\hline OraP11 & Uncultured clone Fr 313 & 95 \\
\hline \multirow[t]{2}{*}{ OraP12 } & Uncultured bacteria WH1, Pseudananabaena & 97 \\
\hline & PCC7508, Oscillatoria limnetica MR1 & 95 \\
\hline OraP13 & $\begin{array}{l}\text { Phormidium subfuscum UTCC } 474 \text {, } \\
\text { Uncultured clone Fr } 048\end{array}$ & 95 \\
\hline OraP14 & Uncultured clone Fr 032 & 95 \\
\hline OraP15 & Uncultured clone Fr 304 & 95 \\
\hline FreP02 & $\begin{array}{l}\text { Phormidium subfuscum UTCC474, Oscillatoria sp. } \\
\text { Ant-G16, Oscillatoria sp. E17 }\end{array}$ & 99 \\
\hline FreP03 & Uncultured clone BGC-032 & 99 \\
\hline FreP04, FreP05, FreP06 & P. murrayii UTCC475 & 98 \\
\hline \multirow[t]{2}{*}{ FreP07 } & Synechococcus sp. PCC7502 & 97 \\
\hline & Phormidium mucicola & 94 \\
\hline FreP16, FreP17 & Uncultured clone LB- 45,46 & 98 \\
\hline FreP18 & Uncultured clone Fr 397 & 94 \\
\hline FreP19 & $\begin{array}{l}\text { Phormidium subfuscum UTCC474, Oscillatoria sp. } \\
\text { G16, Oscillatoria sp. E17 }\end{array}$ & 99 \\
\hline FreP20 & Microcoleus vaginatus PCC9802 & 95 \\
\hline FreP21 & Phormidium murrayii UTCC475 & 98 \\
\hline FreP22, FreP23, FreP24, FreP25, FreP26 & Anabaena cylindrica NIES 19 & 98 \\
\hline FreP27, FreP28 & Anabaena cylindrica NIES 19 & 97 \\
\hline FreP29, FreP30 & Anabaena cylindrica NIES 19 & 93 \\
\hline FreP32 & N. spumigena UTEX-B2092 & 97 \\
\hline FreP31 & N. spumigena UTEX-B2092 & 98 \\
\hline FreP33 & N. harveyana UTEX B2093 & 98 \\
\hline SalP01, SalP02, SalP04, SalP12, SalP03, SalP08, SalP11 & Oscillatoria sp. Ant-Salt, Ant-G17, Ant-Brack3 & 99 \\
\hline SalP05, SalP10 & Oscillatoria sp. Ant-Salt, Ant-G17, Ant-Brack3 & 98 \\
\hline SalP06 & Oscillatoria sp. Ant-Salt, Ant-G17, Ant-Brack3 & 97 \\
\hline SalP07 & Ant-Salt, G17, Oscillatoria priestleyii UTCC476 & 98 \\
\hline SalP09 & Leptolyngbya sp. PCC7104 & 97 \\
\hline
\end{tabular}

The phylotypes with high similarity to Nostocales clustered into four groups NI, NII, NIII and NIV respectively (Fig. 1). Approximately $30 \%$ of the clones from Fresh Pond and $3.4 \%$ of the clones from Orange Pond grouped into the phylotypes of the genus Nostocales, whereas no clones from the clone library of Salt Pond were clustered similarly. For the first time it was possible to obtain sequence data of Antarctic cyanobacterial communities that belonged to the nitrogen-fixing genera Nodularia sp. and Anabaena sp. Clones obtained from Orange Pond only clustered with the NI subcluster of the genus Nostoc $\mathrm{NI}$, whereas Fresh Pond clones clustered with three subclusters of NII, NIII and NIV. The cluster NII was formed by clones obtained from Fresh Pond, which also clustered with heterocyst-forming cyanobacteria and the closest match being to the sequence of Anabaena cylindrica NIES 19. The cluster NIV comprised species belonging to the genus Nodularia. These clones had 97-98\% similarity to Nodularia spumigena or Nodularia harveyana. In the cluster NIII, phylotypes were obtained which showed a minimal dissimilarity of $7 \%$ to other sequences in GenBank and had the highest similarity to Anabaena cylindrica NIES 19, possibly indicating the presence of a novel Antarctic Nostocales phylotype.

As described above, the Oscillatoriales clones obtained are grouped into eight different clusters comprising 19 different phylotypes (Fig. 2). For Fresh, Orange and Salt Ponds clones were identified which grouped into six, four and two clusters respectively. There were two subclusters within the oscillatorian clades, which only contained clones obtained from the Fresh Pond clone library. In the first cluster (OCIII), the clones grouped together with Phormidium murrayi, which was isolated from a pond on McMurdo Ice Shelf. The second Fresh Pond cluster (OCV), comprised clones of Fresh Pond, Phormidium mucicola as well as clones from Lake Fryxell, Dry Valleys. It was possible to identify one group of clones from Orange Pond which was not present in samples from either Fresh or Salt Ponds, and which clustered within the clade OCVIII. This cluster was comprised of clones of Orange Pond and reference sequences, including uncultured clones from Lake Fryxell and Arctic cyanobacterial strains. Clusters $\mathrm{OCI}, \mathrm{OCIV}$ and OCVI comprised clones from Fresh and Orange Ponds as well as the reference 


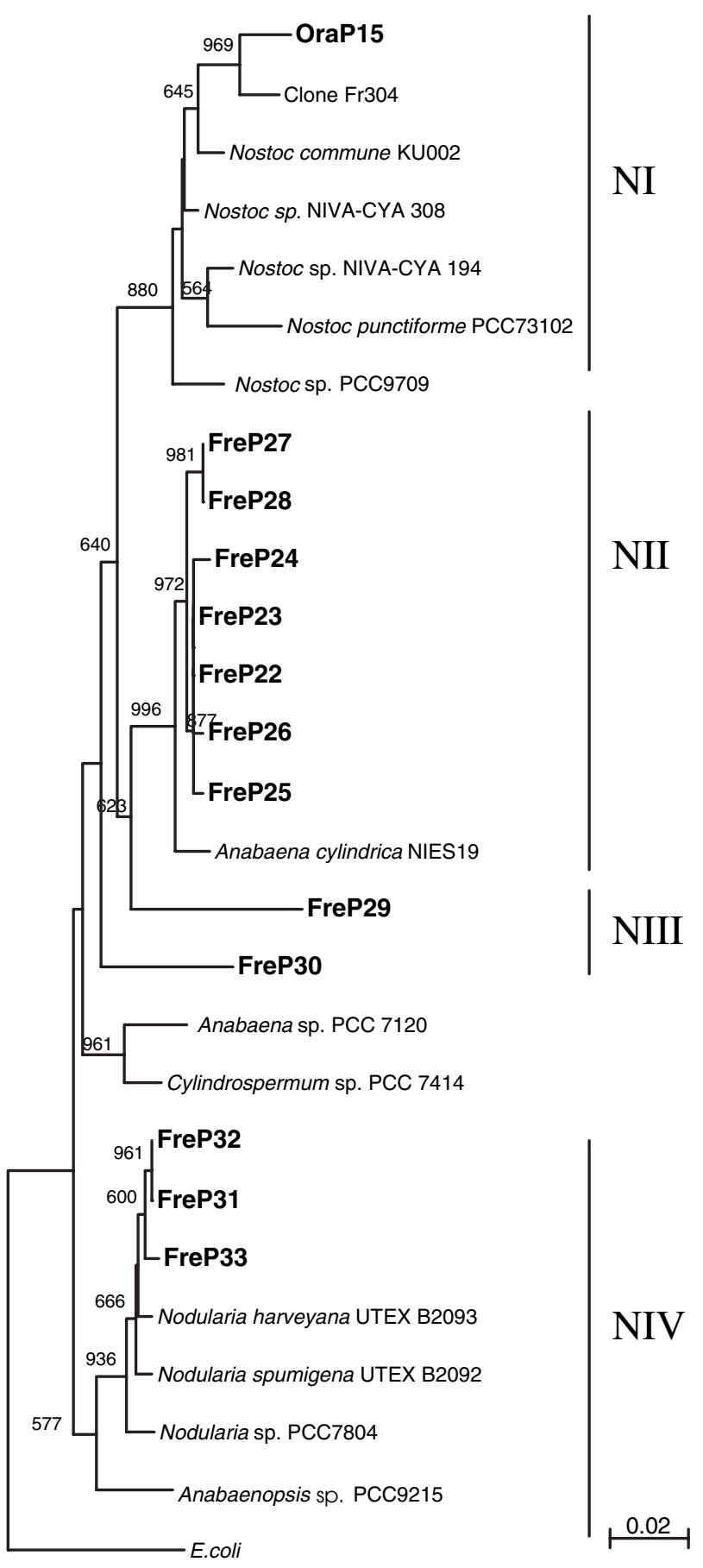

Fig. 1. Phylogenetic analysis of $16 \mathrm{~S}$ rDNA clones with a relationship to the order Nostocales. Sequences were identified through the construction of clone libraries from the cyanobacterial mat communities of the three meltwater ponds Fresh, Orange and Salt Ponds, McMurdo Ice Shelf. The phylogenetic relationship was constructed using the Neighbour-Joining Method. Bootstrap values $\geq 500$ (after 1000 data re-sampling events) are shown. The scale is 0.02 mutations per nucleotide positions. Sequence data obtained in this study are shown in bold letters. FreP, Fresh Pond; OraP, Orange Pond. sequences from Lake Fryxell. Cluster $\mathrm{OCl}$ also contained reference sequences from the meltwater ponds investigated, including Orange Pond, other locations in Antarctica, and Arctic reference sequences. Cluster OCIV contained phylotypes that grouped with uncultured clones from Lake Bonney, Dry Valleys.

In contrast to Fresh and Orange Ponds, the clones from Salt Pond grouped with only two of the oscillatorian clusters, OCII and OCVII. These clones were delineated from 16S rDNA sequences from Fresh and Orange Ponds, Lake Fryxell or Lake Bonney. Cluster OCII comprised the majority of the Salt Pond clones. The sequences showed high similarity $(99 \%)$ to two reference sequences, namely $O$. priestley, which was isolated from a pond on the McMurdo Ice Shelf, and Oscillatoria sp. Ant-Salt (99\%) which originated from Salt Pond. The other Salt Pond cluster, OCVII, contained representative clones of Oscillatoria sp. Ant-SOS and Leptolyngbya sp.

The Shannon-Wiener index was applied for the coverage $(H)$ of diversity (Good, 1953). The index showed that almost all the diversity in Salt Pond clone library was detected with $H=96$. The coverage was also high for Fresh $(H=86.956)$ and Orange Ponds $(H=90.196)$ (Good, 1953).

\section{Discussion \\ Morphological characterization of cyanobacterial diversity}

Microscopic observations agreed with previous morphological studies on the three ponds Fresh, Orange and Salt (Hitzfeld et al., 2000; Nadeau and Castenholz, 2000). The cyanobacterial mat communities were dominated by oscillatorian species as well as species belonging to the order Nostocales. No unicellular cyanobacteria were identified in the morphological or genotypic analysis. This agrees with studies on Antarctic microbial communities by Stal (2000) and Taton and colleagues (2003), whereas other studies such as Olson (Olson et al., 1998) have observed coccoid cyanobacteria in Lake Bonney, McMurdo Dry Valleys. The broad distribution of $P$. cf. deflexum (morphogroup A) and $P$. autumnale (morphogroup B) has also been recorded in previous studies (Nadeau and Castenholz, 2000). It was suggested that the oscillatorian species are likely to be distributed based on the different conductivities of meltwater ponds (Broady and Kibblewhite, 1991). Oscillatoria priestley, for example, is preferentially found in hypersaline environments such as Salt Pond; however, in this study it was also present in Fresh Pond. The absence of Nostoc sp. in Salt Pond is also considered to be due to its conductivity (Howard-Williams et al., 1990). In contrast to Nostoc sp., the Nodularia sp. morphotype was present in all three ponds and therefore its abundance seems to be independent of conductivity. 


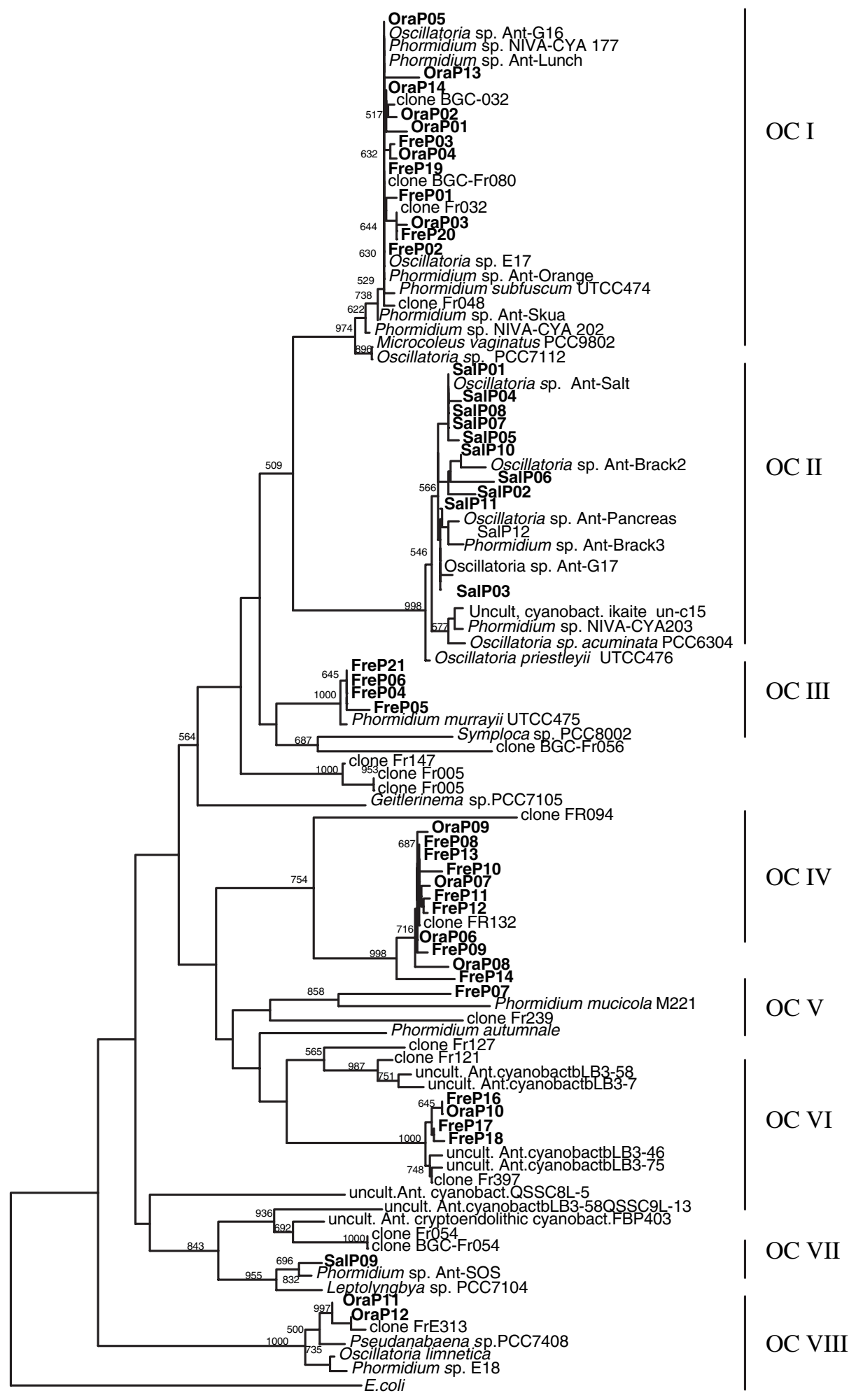

Fig. 2. Phylogenetic analysis of $16 \mathrm{~S}$ rDNA clones with a relationship to the order Oscillatoriales. Sequences were identified through the construction of clone libraries from the cyanobacterial mat communities of the three meltwater ponds Fresh, Orange and Salt Ponds, McMurdo Ice Shelf. The phylogenetic relationship was constructed using the Neighbour-Joining Method. Bootstrap values $\geq 500$ (after 1000 data re-sampling events) are shown. The scale is 0.02 mutations per nucleotide positions. Sequence data obtained in this study are shown in bold letters. FreP, Fresh Pond; OraP, Orange Pond; SalP, Salt Pond. 
Even though this morphological study was limited by the difficult taxonomy and the plastic morphology of cyanobacteria, it revealed that cyanobacterial communities are relatively consistent in their morphological diversity over long time periods (Howard-Williams et al., 1990).

Because of its immobility and fragile vegetative cellheterocyst structure, the genus Nodularia sp. is generally not considered to be well adapted to conditions in microbial mats. However, it has frequently been found in matforming communities on the McMurdo Ice Shelf (Stal, 2000; Taton et al., 2003), potentially because their ability to fix nitrogen is advantageous in these highly oxic environments, as shown for Nostoc sp. in microbial communities of lakes in the McMurdo Dry Valleys (Olson et al., 1998). The three investigated ponds were shown to have different levels of dissolved organic nitrogen (Table 1), which negatively correlates with the abundance of morphotypes belonging to the nitrogen-fixing order Nostocales.

\section{Phylogenetic characterization of cyanobacterial diversity}

For the first time it was possible to obtain phylotypes of Nodularia sp., Nostoc sp. and Anabaena sp. from Antarctic environmental samples via the construction of a clone library. However, it was only possible to obtain phylotypes belonging to Nodularia sp. from Fresh Pond even though Nodularia sp. was observed microscopically in all three ponds. This discrepancy was also encountered during the analysis of a clone library from a cyanobacterial mat community from Lake Fryxell (Taton et al., 2003). These apparent contradictions might be related to the particular species present in Antarctica and could suggest the presence of a novel Antarctic Nodularia phylotype, possessing regions of the $16 \mathrm{~S}$ rDNA not recognized by the polymerase chain reaction (PCR) primers employed. Morphological features of the species, however, suggest the classification of the identified phenotype as Nodularia cf. harveyana, which is a cosmopolitan species (Moffitt et al., 2001). This is also supported by a $16 \mathrm{~S}$ rDNA sequence similarity of $98 \%$ to the reference strains $N$. harveyana and $N$. spumigena. Sequence analysis of single trichomes might be a useful approach for a more conclusive genotypic classification of Nodularia sp. present in Antarctica.

Clones with a high similarity to Nostoc sp. were only obtained from Orange Pond, although the phenotype Nostoc sp. was also observed in Fresh Pond. However in Fresh Pond, clones of the Anabaena sp. phylotype were identified, even though the phenotype Anabaena sp. was not observed microscopically. Previous morphological studies have revealed the presence of Anabaena sp. in these ponds (Howard-Williams et al., 1990; Hitzfeld et al., 2000). Possible explanations for this disagreement between genotypic and phenotypic characterization may be due to this low abundance of Anabaena sp. or ambiguous morphotypes. Furthermore, a phylotype was identified with only $93 \%$ similarity (Anabaena sp. NIES 19) to any $16 \mathrm{~S}$ rDNA database entry in GenBank, which suggests the potential presence of a novel lineage of heterocystous cyanobacteria in Antarctica.

The cyanobacterial community in Salt Pond was shown to contain less diversity either than in Fresh or Orange Ponds. The clone library data suggested that $O$. priestley, and the psychrotolerant Oscillatoria sp. Ant-Salt are the dominant genotypes, even though the clone library data can only semiquantify species abundance. This phylogenetic analysis supported the present morphological investigations as well as those of previous studies. Salt Pond clones formed a lineage with Oscillatoria sp. Ant-SOS and Leptolyngbya sp. Oscillatoria sp. Ant-SOS was isolated from 'Son of Salt' Pond (SOS Pond, unofficial name) (Nadeau and Castenholz, 2000), which is situated in very close proximity to Salt Pond. Interestingly, Fresh Pond lays c. $300 \mathrm{~m}$ from Orange and $50 \mathrm{~m}$ from Salt Pond. However, the cyanobacterial communities of Fresh and Orange Ponds are more similar to each other than to Salt Pond. The phylogenetic approach used revealed here that there is greater diversity present in Fresh and Orange Ponds than the initial morphological characterization suggested. Furthermore, the number of phylotypes identified is likely to be an underestimate because of the selectivity of the method and the sample size. The morphological diversity observed in Salt Pond, however, was not indicated by the phylogenetic characterization. Possible explanations for these differences included the variable morphology of certain species or the inherent selectivity of the molecular method. Isolation of specific morphotypes and the sequencing of $16 S$ rDNA obtained from single trichomes may overcome these problems.

\section{Antarctic hypersaline environments}

As shown in Table 1, the major defining characteristic of Salt Pond is its high conductivity $(52900 \mu \mathrm{S} / \mathrm{cm})$. In this habitat therefore, cyanobacteria not only have to survive the metabolic stress of low temperature, desiccation and high UV irradiation, but they also have to maintain their intracellular osmotic equilibrium against extreme conductivities. Cyanobacteria belonging to the order Oscillatoriales, such as Oscillatoria sp., Microcoleus sp. and Phormidium sp., are often found in hypersaline environments (Oren, 2000), in agreement with the results of this study. Studies on O. priestley also demonstrated a higher UV sensitivity than P. murrayi. However, O. priestley was able to utilize its motility more effectively to retreat into mat layers with lower UV radiation (Quesada and Vincent, 1997). Microcoleus chthonoplates has been found to produce trehalose and glycosylglycerol as organic 
compatible solutes in order to maintain intracellular salt concentrations. Further, M. chthonoplates was shown to interact with bacteria and archaea to reduce sulfide levels which can inhibit oxygenic photosynthesis (Oren, 2000; Stal, 2000). However, to our knowledge, little is known about the specific mechanisms involved in the regulation of intracellular salt concentrations in cyanobacteria inhabiting the hypersaline meltwater ponds of Antarctica.

Low temperatures also increase stress with psychrotolerant cyanobacteria having to perform photosynthesis and other housekeeping functions under suboptimal conditions. It is likely that only a few cyanobacterial species are able to adapt to and grow under these extreme conditions over a long period, which results in the low levels of diversity and speciation observed. Another possible explanation for the low biodiversity of Salt Pond might be that the total area of hypersaline ponds is smaller than that of other aquatic systems with low or medium conductivities such as Fresh and Orange Ponds, and therefore only a smaller number of species can be supported. The clones identified formed a shared lineage with Arctic reference strains and several uncultured clones from ikaite tuffa columns (Greenland) (Stougaard et al., 2002), suggesting a cosmopolitan distribution of these halotolerant taxa.

\section{Distribution of cyanobacteria}

To date, morphological studies have concluded that cyanobacteria originated in temperate climates and therefore polar cyanobacterial species were not assumed to be endemic in Antarctica (Vincent, 2000b). These studies were supported by the assumption that their dispersal was too slow to evolve into such a large range of species and speciation in the ice-free periods of polar regions (Castenholz, 1992). The present investigation is in concordance with Taton and colleagues (2003), where different levels of distribution were postulated for Antarctic cyanobacterial phylotypes. In our study the Antarctic phylotypes of the order Oscillatoriales comprised phylotypes which have only thus far been identified in Antarctic environments (lineages OCIII, OCIV and OCVI) or only in polar environments (lineages $\mathrm{OCl}, \mathrm{OCII}$ ), as well as those that had high similarities to temperate cyanobacterial phylotypes (lineages OCV, OCVII and OCVIII). The Nostoc sp. phylotypes identified clustered with the Nostoc sp. of Lake Fryxell; however, the similarity between the sequences did not exceed $95 \%$. These results concur with the phylogenetic analysis of the cyanobacterial mat communities of Lake Fryxell (Dry Valleys) (Taton et al., 2003). Some of the clusters which were defined by Taton and colleagues (2003) as novel and new evolutionary branches from Lake Fryxell, were also present in Fresh and Orange Ponds. The combined results of these studies also indicated that psychrotolerant and psychrophilic cyanobacterial species are present in the Antarctic communities. It has been suggested that psychrotolerant rather than psychrophilic characteristics would be more beneficial for survival in freshwater systems, including meltwater ponds, because of the rapid diurnal changes of temperatures during the summer (Tang et al., 1997). Finally, the phylotypes obtained in this study did not cluster with any reference sequences obtained from Vestfold Hills, East Antarctica, which might be due to the limited available data on oscillatorian phylotypes.

The meltwater system south of Bratina Island is part of a region on the McMurdo Ice Shelf which has the most extensive microbial growth and largest non-marine biota in southern Victoria Land (Howard-Williams and Vincent, 1989; Broady and Weinstein, 1998). Therefore, it was suggested that microbiota, such as dried cyanobacterial mat material, play an important role as inocula through the dispersal by the strong Antarctic winds for freshwater and saline habitats in the ice-free regions of Victoria Land (Saxena, 1982). Recent studies also showed that cyanobacterial material was found in a $500 \mathrm{~km}^{2}$ radius surrounding the meltwater systems of McMurdo Ice Shelf (Vincent, 2000a). The present study also supported this hypothesis of a 'biogenetic nuclei' (Saxena, 1982), as most of the genotypes obtained from Fresh Pond and Orange Pond have a very high similarity to those obtained from Lake Bonney and Lake Fryxell which are situated in the arid Dry Valleys of Victoria Land.

In summary, this study has revealed that even though the ponds investigated are in close proximity, their phylogenetic communities are not similar. However, known polar strains clustered together with clones obtained from all the three ponds. These data have provided a better understanding of the complex diversity and distribution of Antarctic cyanobacterial mat communities inhabiting meltwater ponds of different conductivities on the McMurdo Ice Shelf. Further genotypic as well as physiological data are needed to describe the continental distribution in Antarctica as well as globally, and the metabolic processes involved in their survival in these extreme environments. This will enhance our understanding on the role of cyanobacteria as the dominant primary-producing organisms in permafrost environments and their role in the evolution of life on earth.

\section{Experimental procedures}

\section{Sampling and sample sites}

Benthic microbial mat material was collected from the meltwater ponds - Salt, Orange and Fresh Ponds (unofficial names) on the McMurdo Ice Shelf, located south of Bratina Island $\left(78.00^{\prime} \mathrm{S}, 165.30^{\prime} \mathrm{E}\right)$ in January 2002 . Water chemistry parameters such as conductivity were obtained as described (Hitzfeld et al., 2000). 


\section{Microscopic observation}

The morphological characterization of the samples was performed with a Zeiss light microscope (Axio Star plus, Jena, Germany). The morphological characterization was based on the literature by Geitler (1932), Broady and Kibblewhite (1991), and Anagnostidis and Komarek (Anagnostidis, 1985; Anagnostidis and Komarek, 1988, 1990). Photo documentation was carried out with a digital camera and $100 \times$ magnification (Axio, Cam HR, Zeiss, Jena, Germany).

\section{Determination of the organic partition}

An aliquot of each sample was lyophilized and the organic content was determined by furnace incineration at $600^{\circ} \mathrm{C}$ for $14 \mathrm{~h}$ (Hitzfeld et al., 2000).

\section{DNA isolation}

Freeze-dried material was used for DNA isolation. An aliquot of $20 \mathrm{mg}$ of the organic partition of freeze-dried material was suspended and ground with a sterile micropestle in $900 \mu \mathrm{l}$ of SLP-buffer [50 mM Tris-HCl (pH 8.3), $40 \mathrm{mM} \mathrm{EDTA,}$ $0.75 \mathrm{mM}$ sucrose]. After re-suspension, $50 \mu \mathrm{l}$ of proteinase $\mathrm{K}\left(10 \mathrm{mg} \mathrm{ml}^{-1} \mathrm{SLP}\right)$ and $50 \mu \mathrm{l} 20 \% \mathrm{w} / \mathrm{v}$ SDS was added. After each addition, the extract was thoroughly vortexed. The mixture was incubated and shaken for $1-2 \mathrm{~h}$ at $55^{\circ} \mathrm{C}$. The extract was then centrifuged at $3000 \mathrm{~g}$ for $3 \mathrm{~min}$ to remove the cell debris. The DNA was extracted with an equal volume of phenol chloroform-isoamyl alcohol $(25: 24: 1)$, mixed and centrifuged at $3000 \mathrm{~g}$ for $3 \mathrm{~min}$. An equal volume of chloroform-Isoamyl alcohol (25:24:1) was then added to the removed aqueous phase and centrifuged at $3000 \mathrm{~g}$ for $3 \mathrm{~min}$. The two steps were repeated twice. The extracted DNA was precipitated with a standard $\mathrm{NaCl}$-ethanol precipitation. The DNA was re-suspended in $100 \mu \mathrm{l}$ of sterile water.

\section{Polymerase chain reaction and cloning}

All PCR reactions were performed using 0.5 unit Taq polymerase (Fischer Biotech, Perth, Australia) in a $25-\mu$ l reaction mix containing $2.5 \mathrm{mM} \mathrm{MgCl}_{2}, 1 \times$ Taq-Polymerase buffer (Fischer Biotech), $0.2 \mathrm{mM}$ dNTPs (Fischer Biotech, Australia) and $0.2 \mathrm{pM}$ forward primer. Thermal cycling was performed in a GeneAmp PCR System 2400 Thermocycler (Perkin Elmer, Norwalk, USA). Polymerase chain reaction amplification of the cyanobacterial 16S rDNA was performed using the cyanobacterial specific primer set 27F1 (5'-AGAGTTT GATCCTGGCTCAG-'3) and 809R (5'-GCTTCGGCACG GCTCGGGTCGATA-'3) (T.P. Salmon and B.A. Neilan, unpublished data). The initial denaturation step at $92^{\circ} \mathrm{C}$ for 2 min was followed by 30 cycles of DNA denaturation at $92^{\circ} \mathrm{C}$ for $20 \mathrm{~s}$, primer annealing at $50^{\circ} \mathrm{C}$ for $30 \mathrm{~s}$, strand extension at $72^{\circ} \mathrm{C}$ for $1 \mathrm{~min}$ and a final extension step at $72^{\circ} \mathrm{C}$ for $7 \mathrm{~min}$. For cloning of the PCR product the p-Gem (R) T Easy Vector System (Promega, Madison, USA) was used. The ligation and transformation were performed according to the manufacturer. For each sample at least 100 positive (insert containing) clones were used for further analysis.

\section{Amplified restriction digest rDNA analysis}

Clones of interest were amplified using vector specific primers and subjected to ARDRA. Amplified restriction digest rDNA analysis was performed on at least 100 positive clones from each sample. Each clone was tested in a separate incubation with two restriction enzymes. Approximately $200 \mathrm{ng}$ of PCR product was digested with $1.5 \mathrm{U}$ of $\mathrm{Alul}$ and ScriF1 (Fermentas, Hanover, USA) in a $10-\mu$ l reaction as described by the supplier. The generated ARDRA patterns were analysed on $2 \%$ and $3 \%$ agarose gels with $1 \times$ TAEbuffer. The ARDRA fragments were stained with ethidium bromide $\left(1 \mu \mathrm{g} \mathrm{ml}^{-1}\right)$ for $10 \mathrm{~min}$. For photo documentation a Gel-DOC Bio-RAD System with Quantity One 4.1R software (BIO-RAD, USA) was used.

\section{Sequencing}

Sequencing of at least two clones was performed for each combination of ARDRA patterns. The primer pair 27F1/809R was also used for sequencing. Automated sequencing was performed using the PRISM Big Dye cycle sequencing system and ABI 3730 Capillary Applied Biosystem (Foster City, CA) using Polymer 7.

\section{Phylogenetic sequence analysis}

Sequence data were analysed using the Applied Biosystem Auto-Assembler computer programme. The sequences were compared in a multiple alignment using the package Clustral x (1.8) (Thompson et al., 1994). Phylogenetic trees were obtained using the Neighbour-Joining Methods, confidence levels were calculated via the Bootstrap-NJ-Methods (Felsenstein, 1978) and the bootstrap re-sampling number was 1000 . The reference strains were obtained via BLAST searches on GenBank.

\section{Nucleotide sequence accession numbers}

16S rRNA gene sequences are available under GenBank accession numbers AY541527-AY541584.

\section{Acknowledgements}

We would like to thank Antarctica New Zealand for providing logistical support during the sampling. Many thanks to Paul Broady (University of Canterbury, New Zealand) and Steve Skinner (Sydney Royal Botanical Garden, Australia) for helping with the morphological analysis of the samples. We would also like to acknowledge the anonymous reviewers for their helpful comments. A.-D.J. is the recipient of research scholarships from the University of New South Wales and the School of Biotechnology and Biomolecular Sciences.

\section{References}

Anagnostidis, K. (1985) Modern approach to the classification system of cyanophytes; 1. Introduction. Arch Hydrobiol Suppl 71: 291-302. 
Anagnostidis, K., and Komarek, J. (1988) Modern approach to the classification system of cyanophytes; 3. Oscillatoriales. Arch Hydrobiol Suppl 50: 327-472.

Anagnostidis, K., and Komarek, J. (1990) Modern approach to the classification system of cyanophytes: 5. Stigonematales. Arch Hydrobiol Suppl 86: 1-73.

Broady, P., and Kibblewhite, A. (1991) Morphological characterization of Oscillatoria (Cyanobacteria) from Ross Island and southern Victoria Land, Antarctica. Antarct Sci 3: 35-45.

Broady, P., and Weinstein, R. (1998) Algae, lichens and fungi in La Gorce Mountains, Antarctica. Antarct Sci 10: 376385.

Castenholz, R.W. (1992) Species usage, concept, and evolution in the cyanobacteria (blue-green algae). J Phycol 28: 737-745.

Castenholz, R.W., and Waterbury, J.B. (1989) Oxygenic photosynthetic bacteria. Group 1. Cyanobacteria. In Bergey's Manual of Systematic Bacteriology. Stanley, J.T., Bryant, M.P., Pfennig, N., and Holt, J.G. (eds). Baltimore, USA: Lippincott Williams and Wilkins, pp. 1710-1806.

De Mora, S.J., Whitehead, R.F., and Gregory, M. (1991) Aqueous geochemistry of major constituents in the Alph River and tributaries in Walcott Bay, Victoria Land, Antarctica. Antarct Sci 3: 73-86.

De Mora, S.J., Whitehead, R.F., and Gregory, M. (1994) The chemical composition of glacial melt water ponds and streams on the McMurdo Ice Shelf, Antarctica. Antarct Sci 6: 17-27.

Ehling-Schulz, M., and Scherer, S. (1999) UV protection in cyanobacteria. Eur J Phycol 34: 329-338.

Felsenstein, J. (1978) Cases in which parsimony or compatibility methods will be positive misleading. Syst Zool 40: 366-375.

Geitler, L. (1932) Cyanophyceae. Rabenhorst's Kryptogamen-Flora von Deutschland, Österreich und der Schweiz. Leipzig: Akademische Verlagsgesellschaft.

Good, I.J. (1953) The population frequencies of species and the estimation to the population parameters. Biometrika 40: 237-264.

Hitzfeld, B., Lampert, C., Späth, N., Mountfort, D., Kaspar, H., and Dietrich, D. (2000) Toxin production in cyanobacterial mats from ponds on the McMurdo Ice Shelf, Antarctica. Toxicon 38: 1731-1748.

Howard-Williams, C., and Vincent, W.F. (1989) Microbial communities in southern Victoria Land streams (Antarctica). I. photosynthesis. Hydrobiology 172: 2738.

Howard-Williams, C., Pridmore, R., Downes, M., and Vincent, W. (1989) Microbial biomass, photosynthesis and chlorophyll a related pigments in the ponds of the McMurdo Ice Shelf, Antarctica. Antarct Sci 1: 125-131.

Howard-Williams, C., Pridmore, R., Broady, P., and Vincent, W. (1990) Environmental and biological variability in the McMurdo Ice Shelf ecosystem. In Antarctic Ecosystems. Ecological Change and Conservation. Kerry, K., and Hempel, G. (eds). Berlin, Heidelberg: Springer Verlag, pp. 23-31.

Keys, J.R., and Williams, K. (1981) Origin of crystalline, cold desert salts in the McMurdo region, Antarctica. Geochimica Cosmochimica Acta 2309: 1981.
Moffitt, M.C., Blackburn, S.I., and Neilan, B.A. (2001) rRNA sequences reflect the ecophysiology and define the toxic cyanobacteria of the genus Nodularia. Int $J$ Syst Evol Microbiol 51: 505-512.

Nadeau, T.L., and Castenholz, R.W. (2000) Characterization of psychrophilic Oscillatorians (Cyannobacteria) from Antarctic Meltwater Ponds. J Phycol 36: 914-923.

Nadeau, T.L., Milbrandt, E.C., and Castenholz, R.W. (2001) Evolutionary relationships of cultivated Antarctic Oscillatorians (Cyanobacteria). J Phycol 37: 650-654.

Olson, J.B., Steppe, T.F., Litaker, R.W., and Paerl, H.W. (1998) $\mathrm{N}_{2}$-fixing microbial consortia associated with the ice cover of Lake Bonney, Antarctica. Microb Ecol 36: 231-238.

Oren, A. (2000) Salt and brines. In The Ecology of Cyanobacteria. Whitton, B.A., and Potts, M. (eds). the Netherlands: Kluwer Academic Publisher, pp. 281-306.

Priscu, J., Fritzen, C., Adam, S., Giovannoni, S., Paerl, H., McKay, P., et al. (1998) Perennial Antarctic lake ice: an oasis for life in a polar desert. Science 280: 20952098.

Quesada, A., and Vincent, W.F. (1997) Strategies of adaptation by Antarctic cyanobacteria to ultraviolet radiation. Eur J Phycol 32: 335-342.

Ross, J.C., and Vincent, W.F. (1998) Temperature dependence of UV radiation effects on Antarctic Cyanobacteria. J Physiol 34: 118-125.

Rudi, K., Skulberg, O.M., Larsen, F., and Jakobsen, K.S. (1997) Strain characterization and classification of oxyphotobacteria in clone cultures on the basis of 16S rRNA sequences from the variable regions V6, V7, and V8. Appl Environ Microbiol 63: 2593-2599.

Saxena, V.K. (1982) Biogenic nuclei involvement in clouds over the Ross Ice Shelf. Antarct J US 17: 212-214.

Smith, M.C., Bowman, A.P., Scott, A.P., and Line, M.A. (2000) Sublithic bacteria associated with Antarctic quartz. Antarct Appl Environ Microbiol 12: 469-472.

Stal, L.J. (2000) Cyanobacterial mats and stromatolites. In The Ecology of Cyanobacteria. Whitton, B.A., and Potts, M. (eds). the Netherlands: Kluwen Academic Publisher, pp. 61-120.

Stal, L.J., Van Gemerden, H., and Krumbein, W.E. (1985) Structure and development of a benthic marine microbial mat. FEMS Microbiol 45: 111-125.

Stougaard, P., Jorgensen, F., Johnsen, M.G., and Hansen, O.C. (2002) Microbial diversity in ikaite tuffa columns, an alkaline, cold ecological niche in Greenland. Environ Microbiol 4: 487-493.

Swithnbank, C.W.M. (1970) Ice movement in the McMurdo sound area of Antarctica. In International Symposium on Antarctic Glaciological Exploration. Crary, A.P. (ed.). Hanover, New Hamphire: International Association of the Science of Hydrology, pp. 472-487.

Tang, E.P.Y., Tremblay, R., and Vincent, W.F. (1997) Cyanobacterial dominance of polar freshwater ecosystems: are high-latitude mat-formers adapted to low temperatures? J Phycol 33: 171-181.

Taton, A., Grubisic, S., Brambilla, E., de Wit, R., and Wilmotte, A. (2003) Cyanobacterial diversity in natural and artificial microbial mats of Lake Fryxell (McMurdo Dry Valleys, Antarctica): a morphological and molecular approach. Appl Environ Microbiol 69: 5157-5169. 
Thompson, J.D., Higgins, D.G., and Gibson, T.J. (1994) CLUSTALw; improving the sensitivity of progressive sequence alignment through sequence weighting, position specific gap penalties and weight matix choice. Nucleic Acids Res 22: 4673-4680.

de la Torre, J.R., Goebel, B.M., Friedmann, E.I., and Pace, N.R. (2003) Microbial diversity of cryptoendolithic communities from the McMurdo Dry Valleys, Antarctica. Appl Environ Microbiol 69: 3858-3867.

Vincent, W.F. (2000a) Evolutionary origins of Antarctic microbiota: invasion, selection and endemism. Antarct Sci 12: 374-385.
Vincent, W.F. (2000b) Cyanobacterial dominance in the polar regions. In The Ecology of Cyanobacteria. Whitton, B.A., and Potts, M. (eds). the Netherlands: Kluwer Academic Publisher, pp. 321-340.

Ward, D., Ferris, M., Nold, S., and Bateson, M. (1998) A natural view of microbial biodiversity within hot spring cyanobacterial mat communities. Microbiol Mol Biol Rev 62: 1353-1370.

Wynn-Williams, D.D. (2000) Cyanobacteria in the deserts-life at the limit? In The Ecology of Cyanobacteria. Whitton, B.A., and Potts, M. (eds). the Netherlands: Kluwer Academic Publisher, pp. 341-366. 